\title{
EFFECT OF FARMER BUSINESS SCHOOL ON COCOA PRODUCTION IN THE SEFWI JUABOSO DISTRICT OF GHANA
}

\author{
*Enoch K. T.; Seth A. \\ Department of Agribusiness, School of Business and Economics, \\ Presbyterian University College, Ghana, P.O. Box 59, Abetifi Kwahu \\ ${ }^{*}$ Corresponding Author
}

DOI: https://doi.org/10.51193/IJAER.2021.7406

\begin{abstract}
Farmer Business School (FBS) which is a component of the specialized extension system of Ghana Cocoa Board was introduced to ensure sustainable and profitable cocoa production among farmers. The program has been on the run for ten (10) years now however, there is a paucity of empirical studies to show the effect of it on cocoa production. This study explore this gab in the Sefwi Juaboso District of Ghana using case study design involving multi-stage sampling procedure to select 100 (50 Farmer Business School participants and 50 non-participants of Farmer Business School) farmers for the study. Findings of the study established that farmers are highly interested in the program. FBS Participants are making higher yield with superior quality cocoa beans than Non-FBS participants. It is recommended therefore to COCOBOD and other stakeholders to adopt measures to promote participation of farmers in FBS so that the country can maintain its position on the world level in terms of yield and quality.
\end{abstract}

Keywords: Farmer Business School (FBS), Cocoa farmers, Cocoa production, Ghana.

\section{INTRODUCTION}

Cocoa farming is a major business in Ghana Mohammed, et al., (2012). The activity generate livelihood for millions of people Laird et al., (2007). The increasing demand for cocoa and the emerging food security issues throw the challenges for increasing yield and quality of cocoa in order to keep-up with the demand while not damaging the health of consumers Fold, (2001). Numerous efforts to increase yield and quality cocoa continue to be roll-out by cocoa sector stakeholders Schroth \& Harvey, (2007). One of these efforts that need a careful study is the Farmer Business School Concept. The concept that seek to promote business consciousness 
International Journal of Agriculture and Environmental Research

ISSN: 2455-6939

Volume: 07, Issue: 04 "July-August 2021"

among farmers so that they can adhered to best agronomic practices to ensure profitable cocoa farming gain grounds in Ghana since 2010 (Bingen et. al., 2003; Yaro, 2013).

Ghana is the second largest cocoa producing country in the world (Rifin, 2013). The country continues with efforts to maintain or even improve on its current position (Rifin, 2013). In the vain of these efforts comes with free inputs for farmers and comprehensive extension delivery. The extension system tries to instill business consciousness in farmers and as well promote sustainable cocoa production through the Farmer Business Education. Sefwi Juaboso Distrct, one of the largest cocoa production regions in Ghana, generating 10\% of Western Region's total cocoa production is well dominated with the cocoa extension and its farmer business training (David \& Asamoah, 2011).

The increasing demand by global cocoa processors for premium quality that is produced in a sustainable manner makes the Farmer Business Education very inevitable (Adams, 2006; Laven, 2010). Though some farmers do not avail themselves of the programs, other Ghanaian cocoa farmers have embraced the Farmer Business education Program (David \& Asamoah, 2011). The education section is organized for cocoa farmers registered farmers in their respective communities. The effect of the Farmer Business School on the yield and quality of cocoa remains a mystery (David \& Asamoah, 2011). A thorough comparative study measuring the yield and quality of cocoa produced by Farmer Business School participants as against that of nonparticipants in Farmer Business School is therefore necessary for ascertaining the success or otherwise of the program (Dormon et. al., 2004).

\section{MATERIALS AND METHODS}

\section{Profile of Sefwi-Juaboso District}

The Juaboso District was created out of the Sefwi Juaboso District in 1988 with Legislative Instrument (LI) 1473 (Boateng, 2012). The district has a surface area of about 1,284 square kilometres and serves as an entry/exit point between La Cote d'Ivoire and the Republic of Ghana (Knudsen \& Fold, 2011). It has a population of about 86,574. It is located in the northern part of the Western Region of Ghana with Sefwi Juaboso as its capital (Knudsen \& Fold, 2011). The district shares borders with Bia West and Asunafo North districts in the North, Asunafo South and Bodi districts to the East, and Suaman District to the south and la Cote d'Ivoire to the West (Boateng, 2012).

Agriculture is the main economic activity in the District. Endowed with Forest Ochrosols and Oxysols soil which is best for cocoa production, the District generates an average of 30,009.14 tonnes of cocoa annually (Boateng, 2012). About $75 \%$ of the workforce in the district is engaged in cocoa farming (Knudsen \& Fold, 2011). 
International Journal of Agriculture and Environmental Research

ISSN: 2455-6939

Volume: 07, Issue: 04 "July-August 2021"

The undulating landscape giving an altitude ranging from 152 to 510 meters above sea level with numerous rivers and streams that drain the area makes the District best for cocoa farming (Boateng, 2012). The District falls within the Tropical Rainforest Climatic Zone, with annual temperatures ranging from $25^{\circ} \mathrm{C}$ to $35^{\circ} \mathrm{C}$ and annual rainfall between $1500 \mathrm{~mm}$ and $1800 \mathrm{~mm}$ (Knudsen \& Fold, 2011). The District experienced two long wet seasons separated by a short and relatively dry season (Vordzogbe et al., 2005). With relative humidity of 90 percent at night and 75 per cent during the day, the dry season is usually characterised by relatively low humidity, but relatively higher during the rainy season (Project Novella, 2003). The vegetation is mostly of Moist, Semi-Deciduous type with important timber species as Odum, Mahogany, Sapele and Wawa (Vordzogbe et al., 2005). These weather conditions and the vegetation as well make the District ideal for cocoa production (Vordzogbe et al., 2005).

\section{Research design}

The interest of this study was obtained from the preliminary investigation require a research design that will allow multi-perspective or holistic exploration of the issue especially within a specified sector like the cocoa sector as such a case study design (one of the comprehensive designs) was adopted for the study. According to Gerring, (2013), a case study which is a specific method of analyzing a problem of a specified population, provides deep illumination into complex issues within complex systems with good grounds for generalizing the findings across the specified population.

The case study design adapted here makes use of questionnaire survey, interviews and physical quality tests such as cut-test, bean count, moisture test and uniformity test to provide a broader assessment of the effect of farmer Business School on cocoa production in the Sefwi Juaboso District of the Western Region of Ghana. Conclusions of the study are grounded in the results of the study and thus avoid speculations.

\section{Method of data collection}

A multi-stage sampling procedure that includes purposive and simple random sampling techniques were employed for the study. The sampling was done in the following stages:

Stage 1: Purposive sampling technic which allows the selection of elements that generate relevant inputs (Sounders et al. 2009) was used to select the Sefwi Juaboso District for the study. The District was selected purposively because it is one of the leading cocoa producers contributing about $10 \%$ of the western region's production and has been running Farmer Business School since 2010. 
International Journal of Agriculture and Environmental Research

ISSN: 2455-6939

Volume: 07, Issue: 04 "July-August 2021"

Stage 2: A list of cocoa-growing communities within the District was obtained from the Cocoa Health and Extension Division's office within the District. The names of the communities were randomized with textfixer's random generator software to generate three (3) communities namely; Sayerano, Juaboso and Bonsu Nkwanta for the study. The textfixer's random generator is simple random sample software. The simple random sampling was adopted in this stage and stage 3 because the unit of analyses share similarity (cocoa production) since it (simple random sampling) is the most efficient tool for analyzing elements with similar characteristics.

Stage 3: A list of 450 (including FBS and Non-FBS participants) cocoa farmers in the three communities selected in stage 2 was obtained from the Cocoa Health and Extension office within the District. The names of the farmers were randomized with textfixer's random generator software to select 100 (50 Farmer Business School participants and 50 nonparticipants of Farmer Business School) farmers for the study. Arrangements were done with the selected farmers such that questionnaires were administered and cocoa samples (600 grams of beans were obtained from the beans of each of the selected farmers) taken from them.

Stage 4: The samples from the two farmer categories obtained in stage 3 were bulked and reduced to a workable sample of 700 grams through thorough bulking and quartering. 300 beans of the resultant work sample for each lot were cut lengthwise except for germinated beans which were cut breadthwise with sharp knives and physical observation was done on them to determine the defects and purity of the beans of each group. Another 300 grams of beans from each sample group were also weighed in a sub-lot of 100 grams with a cocoa scale. The weighed 300 grams beans in 100 grams lots were counted and the average bean count was expressed per 100 grams. The uniformity index of the sample was determined by visually sorting the unusual beans from the 300 gram weighed beans and striking the percentage of such by the use of a scientific calculator. For the moisture test, a cup electrode Aquaboy (a moisture meter) was used to determine the moisture content of the beans. The process is such that 10 beans were loaded into the cup of the aquaboy and the reading button was clicked to indicate the moisture content of the beans after the cup is well closed. This was done three times and the average moisture reading was taken for each sample group.

Stage 5: Purposive sampling was used to select and interview the District Extension officers. , 1 QCC officer (the district head) and 2 transporters. The officer was believed to have in-depth knowledge about the farmer business school and cocoa production in the District hence his selection.

\section{Data Analysis}


For the analyses, the quantitative data were analyzed with SPSS version 20.0 and Minitab-16 to produce frequency distribution tables. The choice of this software is based on the fact that they allow varied exploration of data and generate accurate results for informed judgement (Bartlett et al., 2001). Analyses of the quantitative data obtained from farmers surveys and the physical assessment of beans provide the basis to infer yield and quality issues in the cocoa sector of the District. The findings from the farmers' surveys and the physical quality assessment of sampled cocoa beans obtained from the selected farmers were validated during a meeting with District Extension Officer.

\section{RESULTS AND DISCUSSIONS}

\section{Farmers' perception and interest in the Farmer Business School programs}

Perceptions drive human attitude and so the best way to explain certain human behaviour is to first investigate the viewpoint they hold in anticipation. Farmers are rational people whose acts are usually backed by pre-conceived views. This section of the analysis seeks to provide understanding to cocoa farmers' perception of the Farmer Business School concept.

Table 2: Respondents perception of Farmer Business School

\begin{tabular}{lll}
\hline Perceptions & Responses & Percentage \\
\hline FBS is very good & No & 4 \\
& Yes & 54 \\
& Uncertain & 42 \\
FBS lessons promote profitable production & No & 0 \\
& Yes & 62 \\
& Uncertain & 38 \\
FBS is a waste of time & & 51 \\
& No & 39 \\
& Yes & 10 \\
I am highly interested in FBS programs & Uncertain & 38 \\
& No & 62 \\
\hline
\end{tabular}

Source: Field data 2021 
The farmers have a positive perception about FBS and this is made clear with majorities (54\%) response that the FBS is very good while $62 \%$ and $51 \%$ respectively affirms that FBS promote profitable production and participation in the program is never a waste of time. $62 \%$ of the respondents express high interest in the FBS program while $38 \%$ of the respondents are not interested in the program

\section{Effect of Farmer Business School on cocoa yield.}

The main purpose of FBS as stated in the first chapter of this study is to equip farmers with requisite business knowledge that will enable them to make gains in farming. This section of the analysis conducts a simple comparison to determine the effect of the FBS on cocoa farms' output (in tonnes)

Table 3: Effect of Farmer Business School on cocoa yield

\begin{tabular}{llll}
\hline Category & Frequency & $\begin{array}{l}\text { Average Expenses/Ha } \\
\text { (GHC) }\end{array}$ & $\begin{array}{l}\text { Average Yield/Ha } \\
\text { (tonne) }\end{array}$ \\
\hline FBS Participants & 50 & 3000 & 1.0000 \\
& & & 0.5625 \\
$\begin{array}{l}\text { Non-FBS } \\
\text { Participants }\end{array}$ & 50 & 2000 & \\
\hline
\end{tabular}

Source: Field data 2021

Table 3 shows FBS Participants investing more in the same size of land than the Non-FBS participants. The FBS Participants farms are yielding almost double the yield of the Non-FBS participants'. This shows that FBS participants see farming as a business and therefore put in the right investment and are thus generating enough gains.

\section{Effect of Farmer Business School on cocoa quality}

Cocoa production is not just about to yield, the quality of the beans affects the price and the demand for the bean. Table 4 was constructed after a physical quality analysis of cocoa beans obtained from FBS participants and Non-FBS participants. The separate analyses of beans from these categories of farmers allow a proper assessment of the FBS program. 
International Journal of Agriculture and Environmental Research

ISSN: 2455-6939

Volume: 07, Issue: 04 "July-August 2021"

Table 4: Category of farmers and their bean quality

\begin{tabular}{|c|c|c|c|c|c|c|c|c|c|c|c|c|}
\hline \multirow[b]{2}{*}{ Category } & \multirow[b]{2}{*}{$\begin{array}{l}\text { Frequen } \\
\text { cy }\end{array}$} & \multicolumn{4}{|c|}{ Physical analyses } & \multicolumn{7}{|c|}{ Cut-test Analyses (\%) } \\
\hline & & $\begin{array}{l}\text { Moisture } \\
(\%)\end{array}$ & $\begin{array}{l}\mathrm{F} / \mathrm{M} \\
(\%)\end{array}$ & $\begin{array}{l}\text { Average } \\
\text { bean } \\
\text { count } / 100 \mathrm{~g}\end{array}$ & $\begin{array}{l}\text { Uniformity } \\
\text { Index }(\%)\end{array}$ & $\begin{array}{l}\text { Mouldy } \\
\text { Beans }\end{array}$ & $\begin{array}{l}\text { Slaty } \\
\text { beans }\end{array}$ & $\begin{array}{l}\text { Germinated } \\
\text { beans }\end{array}$ & $\begin{array}{l}\text { Weevil } \\
\text { infested }\end{array}$ & $\begin{array}{l}\text { Other } \\
\text { defects }\end{array}$ & $\begin{array}{l}\text { Percent } \\
\text { purity }\end{array}$ & Grade \\
\hline $\begin{array}{l}\text { FBS } \\
\text { Participants }\end{array}$ & 50 & 6.8 & 0.000 & 88 & 13.2 & 0.3 & 1.0 & 0.7 & 0.0 & 0.0 & 98.0 & I \\
\hline $\begin{array}{l}\text { Non-FBS } \\
\text { Participants }\end{array}$ & 50 & 9.5 & 3.000 & 104 & 12.0 & 2.0 & 9 & 6 & 0.0 & 0.0 & 83.0 & $\mathrm{SS}$ \\
\hline $\begin{array}{l}\text { All put } \\
\text { together }\end{array}$ & 100 & 7.4 & 0.200 & 100 & 12.3 & 0.7 & 1.3 & 1.0 & 0,7 & 0.0 & 96.3 & I \\
\hline
\end{tabular}

Source: Field data, 2020 
The moisture content of the beans from FBS participants was within the permissible limit (between 0.0 -to-7.5) but high $(9.5 \%)$ for the Non-FBS participants' sample. Foreign matter including bean placenta was high up to $3 \%$ (3grams per 300 grams of beans) for beans from NonFBS participants. Beans from FBS participants were without foreign matter. A combination of beans from the two categories of farmers shows a lower foreign matter content $(0.2 \%)$.

On bean count, FBS participants farmers produce heavy beans (88 beans per 100grams) compared to Non-FBS participants (104 beans per 100grams). Though bean weight is largely attributed to plant variety, climatic conditions and harvesting time, post-harvest practices such as delayed pod breaking and fermentation also affect beans' weight. The science behind this is that sugar breakdown continues until the beans get dried and so any undue delay will lead to excess loss of sugar which usually gives weight to the beans.

The uniformity index was high for beans from all the categories even for the combined beans. A follow-up on some of the farmers from the various categories shows that none of them segregates their cocoa according to size. The cut-test results show that FBS participant farmers produce premium quality beans with $98 \%$ purity while Non-FBS participants are producing substandard cocoa with $83 \%$ purity. When the beans from the two categories of farmers were bulked and examine as a single sample, the cut-test result was of premium quality. This means that beans quality may reduce if the FBS participants' population or production from the NonFBS participants dominates that of the FBS participants. Again this finding confirms Mbonomo et al, (2016) assertion that some farmers are short-cutting recommended agricultural practices.

\section{ANOVA Analysis}

Exploring the data in table 4, analyses of variance were conducted with the percent purity of the beans from the various categories as examined. This analysis was conducted to determine whether significance exist (in terms of beans produced) among the two categories of cocoa farmers within the Sefwi-Juaboso District. Table 5 displays the ANOVA result. 
International Journal of Agriculture and Environmental Research

ISSN: 2455-6939

Volume: 07, Issue: 04 "July-August 2021"

Table 5: ANOVA: Category of farmers and their bean quality

\begin{tabular}{llllll}
\hline Source & DF & SS & MS & F & P \\
\hline Factor & 2 & 404.78 & 202.39 & 51.11 & 0.000 \\
Error & 6 & 23.76 & 3.96 & & \\
& & & & & \\
\hline Total & $\mathbf{8}$ & $\mathbf{4 2 8 . 5 4}$ & & &
\end{tabular}

Significant level $=0.05$

The ANOVA analysis shows a larger F-value of 51.11 and a smaller P-value of 0.000 (less than 0.05). These observations $(\mathrm{P}=0.000$ and $\mathrm{F}=51.11)$ indicate inconsistency with the obvious Null hypothesis and hence the rejection of the null hypothesis: "FBS have no significant effects on the physical quality of cocoa beans". The alternative hypothesis "FBS have significant effects on the physical quality of cocoa beans" is however upheld. This finding confirms the assertion of Afoakwa et al., (2012) that bean quality is reduced when recommended practices are not adhered to.

\section{KEY FINDINGS}

The study shows that farmers have a positive perception of the Farmer Business School concept and are highly interested in it. The study also reveals higher investment and higher yield per field of the same size of land by FBS Participants than Non-FBS participants. From a beans quality perspective, FBS have significant effects on the physical quality of cocoa beans

\section{CONCLUSION}

It can be concluded that Non-FBS participants are deviating from recommended post-harvest practices hence producing low yield and poor quality cocoa beans. While the FBS participant farmers are investing recommended cash and effort and are hence generating higher yield and premium quality beans. Ghana's cocoa yield and quality will therefore reduce if measures are not taken to ensure farmers adherence to recommended agricultural practices. 
International Journal of Agriculture and Environmental Research

ISSN: 2455-6939

Volume: 07, Issue: 04 "July-August 2021"

\section{REFERENCES}

Abankwah, V., Aidoo, R., \& Osei, R. K. (2010). Socio-economic impact of government spraying programme on cocoa farmers in Ghana. Journal of Sustainable Development in Africa, 12(4), 116-126.989.

Abenyega, O., \& Gockowski, J. (2003). Labor practices in the cocoa sector of Ghana with a special focus on the role of children. STCP/IITA Monograph, IITA, Ibadan, Nigeria. http://hubrural.org/IMG/pdf/stcp_ghana_labor_practices.pdf, (Accessed 24 April 2018).

Adeyeye, E. I., Akinyeye, R. O., Ogunlade, I., Olaofe, O., \& Boluwade, J. O. (2010). Effect of farm and industrial processing on the amino acid profile of cocoa beans. Food chemistry, 118(2), 357-363.

Adjinah, K.O. and Opoku, I.Y. (2010) The Cocoa Diseases and Pest Control (CODAPEC): Achievements and Challenges myjoyonline - Myjoyonline.com Feature Article, Wed, 28 Apr 2010

Afoakwa, E.O. (2008) Cocoa and chocolate consumption- Are there aphrodisiac and other benefits for human health? S. Afr J ClinNutr, 21 (3) 107-113

Afoakwa, E. O., Quao, J., Takrama, J., Budu, A. S., \&Saalia, F. K. (2013). Chemical composition and physical quality characteristics of Ghanaian cocoa beans as affected by pulp pre-conditioning and fermentation. Journal of food science and technology, 50(6), 1097-1105.

Ahenkorah, Y.; Akrofi, G.S. and Adri, A. K. (1974) The end of the first cocoa shade and manorial experiment at the Cocoa Research Institute of Ghana Journal of HorticulturalScience 49:43-51

Aikpokpodion, P.O. (2007) Genetic diversity in Nigerian cacao, Theobroma cacao L. collections as revealed by phenotypic and simple sequence repeats marker. $\mathrm{PhD}$ Thesis submitted to the University of Ibadan, Nigeria. $147 \mathrm{pp}$

Aikpokpodion, P.O.; Motamayor, J.C.; Adetimirin, V.O.; Adu-Ampomah, Y.; Ingelbrecht, I.; Eskes, A.B.; Schnell, R.J. and Kolesnikova-Allen, M. (2009) Genetic diversity assessment of sub-samples of cacao, Theobroma cacao L. collections in West Africa using simple sequence repeats marker. Tree Genetics and Genome 5:699-711 
International Journal of Agriculture and Environmental Research

ISSN: 2455-6939

Volume: 07, Issue: 04 "July-August 2021"

Annemarie M. \& Ulrich S. (2017) Farmer Business School for Cocoa producers in West and Central Africa Sustainable Smallholder Agri-Business Program Cocoa -Food Link Program (FED 2014/ 349-955)

Arnould, E.; Plastina, A. and Ball, D. (2009) Does fair-trade deliver on its core value proposition: Effects on income, educational attainment, and health in three countries. Journal of Public Policy and Marketing, 28(2), 186-201.

Asfaw, S.; Mithofer, D. and Waibel, H. (2010) What impact are E.U. supermarket standards having on developing countries' export of high-value horticultural products: Evidence from Kenya. Journal of International Food \& Agribusiness Marketing, 22, 252-276.

Aryeetey, E. (2007) State of the Ghanaian Economy, 2007; Report of the Institute of Social, Statistical and Economic Research, ISSER, UG, Legon, Ghana

Awuah, P. K. (2002) The Success Story of Cocoa Processing and Chocolate Manufacturing in Ghana, David Jamieson \& Associates Ltd., Essex U.K. pp 1-4, 33-56.

Akgün, A. E., Keskin, H., \&Ayar, H. (2014). Standardization and adaptation of international marketing mix activities: A case study. Procedia-Social and Behavioral Sciences, 150, 609-618.

Schwan, R. F., \& Fleet, G. H. (2014). Methods of Cocoa Fermentation and Drying. In Cocoa and Coffee Fermentations.CRC Press. 12(14) 88-145.

Aneani, F., Anchirinah, V. M., Owusu-Ansah, F., \&Asamoah, M. (2012). Adoption of some cocoa production technologies by cocoa farmers in Ghana. Sustainable Agriculture Research, 1(1), 103.

Anim-Kwapong, E., Appiah, M. R., \&Osei-Bonsu, K. (2007). A review of the factors affecting the quality of processed cocoa beans in Ghana. Journal of the Ghana Science Association, 9(1), 106-119.

Appiah-Kubi, K. (2001). State-owned enterprises and privatisation in Ghana. The Journal of Modern African Studies, 39(2), 197-229.

Aprotosoaie, A. C., Luca, S. V., \&Miron, A. (2016). Flavor chemistry of cocoa and cocoa products-an overview. Comprehensive Reviews in Food Science and Food Safety, 15(1), 73-91. 
Asamoah, M., Ansah, F. O., Anchirinah, V., Aneani, F., \&Agyapong, D. (2013). Insight into the standard of living of Ghanaian Cocoa Farmers. Greener Journal of Agricultural Sciences, 3(5), 363-370.

Asare, E. (2011). Modelling cocoa farmer behaviour concerning the chemical control of capsid in the Sekyere area Ashanti Region, Ghana (Doctoral dissertation).

Asuming-Brempong S., Sarpong D.B., Anyidoho N.A., Kaplinsky R., Leavy J., (2008) Mapping sustainable production in Ghanaian cocoa. Report to Cadbury, Accra,Malaysian Cocoa Journal, 11(8), 6-96.

Aulakh, J., \& Regmi, A. (2013). Post-Harvest Food Losses Estimation-Development of Consistent Methodology Food and Agriculture Organization of the United Nations http://www. fao. org/_6-13-13. pdf(Accessed 27 April 2018).

Awudzi, G. K., Cudjoe, A. R., Hadley, P., Hatcher, P. E., \& Daymond, A. J. (2017). Optimizing mirid control on cocoa farms through complementary monitoring systems. Journal of Applied Entomology, 141(4), 247-255.

Ayagre, P., \& Osei, V. (2015). An Evaluation of Internal Control Systems: Evidence from Ghana's Cocoa Industry. MERC Global's International Journal of Management, 3(1), 01-15.

Azhar, I., \& Lee, M. T. (2004). Perspective for cocoa cultivation in Malaysia: Relook at the economic indicators. Malaysian Cocoa Journal, 1(2), 6-22.

Baah, F., \& Anchirinah, V. (2011). A review of Cocoa Research Institute of Ghana extension activities and the management of cocoa pests and diseases in Ghana. American Journal of Social and Management Sciences, 2(1), 196-201.

Barbosa de Lima, A. C.; Keppe, A. L. N.; Maule, F. E.; Sparovek, G.; Correa -Alves, M. and Maule, R. F. (2009) Does certification make a difference? Impact assessment study onFSC/SAN certification in Brazil. Piracicaba, Sao Paulo, Brazil: Imaflora.

Barrientos, S., \& Bobie, A. O. (2016). Promoting gender equality in the cocoa-chocolate value chain: Opportunities and challenges in Ghana. GDI Working Paper 2016-006. Manchester, UK: University of Manchester.

Barrientos, S.W.; Asenso-Okyere, K.; Assuming-Brempong, S.; Sarpong, D.; Anyidoho, N.A. and Kaplinsky, R. (2008) Mapping Sustainable Production in Ghanaian Cocoa - A Report to Cadbury by Institute of Development Studies and the University of Ghana. 
Bartlett, J. E., II; Kotrlik, J. W.; Higgins, C. (2001). Organizational research: Determining appropriate sample size for survey research. Information Technology, Learning, and Performance Journal. 19 (1): 43-50.

Besseah, F. A., \& Kim, S. (2014). Technical efficiency of cocoa farmers in Ghana. Journal of Rural Development, 37(2), 159-182.

Bingen, J., Serrano, A., \& Howard, J. (2003). Linking farmers to markets: different approaches to human capital development. Food policy, 28(4), 405-419.

Bosompem, M., \& Mensah, E. (2006). Occupational hazards among cocoa farmers in the Birim south district in the eastern region of Ghana. Basic education, 9(7), 60-69

Breisinger, C. D. X., Kolavalli, S., \&Thurlow, J. (2008). The Role of Cocoa in Ghana's Future Development, Ghana Strategy Support Program (GSSP). International Food Policy Research Institute, 17(1): 40-50.,.

Rottiers, H., Sosa, D. A. T., Van de Vyver, L., Hinneh, M., Everaert, H., De Wever, J., \& Dewettinck, K. (2018). Discrimination of Cocoa Liquors Based on Their Odor Fingerprint: a Fast GC Electronic Nose Suitability Study. Food Analytical Methods, 1-14.

Camu, N., De Winter, T., Addo, S. K., Takrama, J. S., Bernaert, H., \& De Vuyst, L. (2008). Fermentation of cocoa beans: influence of microbial activities and polyphenol concentrations on the flavour of chocolate. Journal of the Science of Food and Agriculture, 88(13), 2288-2297.

Chery, W. (2015). Factors Influencing Sustainable Cocoa Production in Northern Haiti. https://digitalcommons.lsu.edu/cgi/viewcontent.cgi ?article $=4082 \&$ context $=$ gradschool_t heses.(Accessed 27 April 2018).

Christopher P. Buttigieg. (2013). The Institutional Models for Financial Supervision: An Analysis, 12-15. Retrieved from http://ssrn.com/abstract=2190501(Accessed 27 April 2018).

CROMME, N., \& ANGA, J. M. (2007). Supply Chain Management for total quality cocoa in Africa. Projekt der The Common Fund for Commodities and ICCO. Elektronische Version unter: www. icco. org/economics/global. aspx, Abrufdatum, 1, 2010.

CocoaSafe. (2014). Training of Master Facilitators (TOMF), 180. Retrieved from http://www.cocoasafe.org/Resources/TOMFManual-English.pdf. (Accessed 27 April 2018). 
International Journal of Agriculture and Environmental Research

ISSN: 2455-6939

Volume: 07, Issue: 04 "July-August 2021"

Cianfrani, C., \& West, J. (2013). Auditing Process-based quality management systems. https://www.qms.org(Accessed 27 April 2018).

Daniels, S., Laderach, P., \& Paschall, M. (2012). Reaching High-Value Markets : fine flavor cocoa in Ghana. Retrieved from https://www.crs.org(Accessed 27 April 2018).

David, S., \& Asamoah, C. (2011). Video as a tool for agricultural extension in Africa: A case study from Ghana. International Journal of Education and Development using ICT, 7(1), 26-41.

Dormon E.N.A., Sakyi-Dawson O, (2009) Exploring opportunities for enhancing the profitability and sustainability of cocoa production in Ghana, in: A. van Huis,A. Youdeowei (Eds.), Towards Enhancing Innovation Systems Performance in Smallholder African Agriculture, Elmina, Ghana. 68-69.

Dongo, L. N., Aigbekaen, E. O., Jayeola, C. O., Emaku, L. A., \& Orisajo, S. B. (2009). Influence of farmers practices on cocoa bean quality: Nigeria field experience. In 9th African Crop Science, Conference Proceedings, Cape Town, South Africa, African Crop Science Society. 28(9) 299-302.

Dormon, E. V., Van Huis, A., Leeuwis, C., Obeng-Ofori, D., \& Sakyi-Dawson, O. (2004). Causes of low productivity of cocoa in Ghana: farmers' perspectives and insights from research and the socio-political establishment. NJAS-Wageningen journal of life sciences, 52(3-4), 237-259.

Duguma, B.; Gockowski, J. and Bakala, J. (2001) Smallholder cacao (Theobroma cacao Linn) cultivation in agroforestry systems of West and Central Africa: challenges and opportunities. AgroforestSyst 51:177-188

Dzahini-Obiatey, H.; Ameyaw, G. A. and Ollennu, L.A. (2006) Control of cocoa swollen shoot disease by eradicating infected trees in Ghana: A survey of treated and replanted areas. Crop Protection, 25, 647-652.

Ehiakpor, D. S., Danso-Abbeam, G., Baah, J. E., Yildiz, F., Hutchins, A., Tamargo, A., MacCarthy, D. S. (2016). Assessment of Climate Change Impacts on Cocoa Production and Approaches to Adaptation and Mitigation: A Contextual View of Ghana and Costa Rica. Environment, Development and Sustainability, 14(1), 121-557.

Elassy, N. (2015). The concepts of quality, quality assurance and quality enhancement. Quality Assurance in Education, 23(3), 250-261. 
International Journal of Agriculture and Environmental Research

ISSN: 2455-6939

Volume: 07, Issue: 04 "July-August 2021"

Essegbey, G. O., \& Ofori-Gyamfi, E. (2012). Ghana Cocoa Industry-An Analysis from the Innovation System Perspective. Technology and Investment, 3(4), 276-286.

Fule, C.B. (2013): Historic cocoa farming in Cameroon: Future for Smallholders?. Available online: http://www.siani.se/news/blog/chi_benieh_fule.(Accessed 27 April 2018).

Fold, N. (2001). Restructuring of the European chocolate industry and its impact on cocoa production in West Africa. Journal of Economic Geography, 1(4), 405-420.

Fountain, A. C., \& Hütz-Adams, F. (2017). Raising Farm Gate Prices Approaches to Ensure a Living Income for Smallholder Cocoa Farmers. International Journal of Biodiversity Science, Ecosystem Services \& Management, 13(1), 444-469.

Gil, M., Orrego, F., Cadena, E., Alegria, R., \& Londono-londono, J. (2016). Effect of Pectin Lyase Enzyme on Fermentation and Drying of Cocoa ( Theobroma cacao L .): An Alternative to Improve Raw Material in the Industry of Chocolate. Food and Nutrition Sciences, 3(3), 215-226.

Gilmour M, (2009). Quality and food safety in a sustainable cocoa supply chain16th International Cocoa Research Conference, Bali.NJAS-Wageningen Journal of Life Sciences, 6(1), 7-14.

Giovannucci, D. and Ponte, S. (2005) The Collective Formulation and Effectiveness of Public and Private Sustainability Standards, Social Science Research Network,

Gockowski, J. and Sonwa, D. (2008) Biodiversity and Smallholder Cocoa Production Systems in West Africa, STCP Working Paper Series Issue 6,

GSS (Ghana Statistical Service), (2010) Population and House Census

Guehi, T. S., Zahouli, I. B., Ban-Koffi, L., Fae, M. A., \& Nemlin, J. G. (2010). Performance of different drying methods and their effects on the chemical quality attributes of raw cocoa material. International journal of food science \& technology, 45(8), 1564-1571.

Haynes, J., Cubbage, F., Mercer, E., \& Sills, E. (2012). The search for value and meaning in the cocoa supply chain in Costa Rica. Sustainability, 4(7), 1466-1487.

Hénard, F., \& Mitterle, A. (2010). Governance and quality guidelines in Higher Education. A review of governance arrangements and quality assurance. Berlim: OECD.http://www.oecd.org/education/imhe/46064461.pdf. (Accessed 27 April 2018). 
Hernandez-Aguilera, J.N., Gómez, M.I., Rodewald, A.D., Rueda, X., Anunu,C., Ruth Bennett, R., and Harold M.E., (2018) Quality as a Driver of Sustainable Agricultural Value Chains: The Case of the Relationship Coffee Model. Business Strategy and the Environment Bus. Strat. Env. 27(1), 179-198.

Zhao, J., \& Fleet, G. (2015). The effect of lactic acid bacteria on cocoa bean fermentation. International Journal of food microbiology, 205, 54-67.

Hounkonnou D., van Huis A., Röling A., Sterk B., (2009) The innovation systems approach proposed for CoS-SIS, in: A. van Huis, A. Youdeowei (Eds.), Towards Enhancing Innovation Systems Performance in Smallholder African Agricul- ture, Elmina, Ghana. $11-14$.

International Cocoa Organization ICCO (2016). International Cocoa Organization. Quarterly Bulletin of Cocoa Statistics, Volume XLII No. 2, Cocoa Year 2015/16, London.

International Cocoa Organization. (2007). Sustainable Cocoa Economy: a Comprehensive and Participatory Approach. Twelfth Meeting, (December 2006), 1-10.

International Cocoa Organization (ICCO). (2009). Guidelines on Best Known Practices in the Cocoa Value Chain. Nineteenth Meeting, (June 2009S), 1-10.

Kitinoja, L., \& Kader, A. a. (2003). Small-Scale Postharvest Handling Practices: A Manual for Horticultural Crops. Postharvest Technology Research and Information Center, (8), 267.

Kolavalli, S., \&Vigneri, M. (2011). Cocoa in Ghana: Shaping the Success of an Economy. Yes Africa Can, 201-217. https://doi.org/10.1596/978-0-8213-8745-0(Accessed 27 April 2018).

Kongor, J. E., Hinneh, M., Van de Walle, D., Afoakwa, E. O., Boeckx, P., \& Dewettinck, K. (2016). Factors influencing quality variation in cocoa (Theobroma cacao) bean flavour profile-A review. Food Research International, 82, 44-52.

Knudsen, M. H., \& Fold, N. (2011). Land distribution and acquisition practices in Ghana's cocoa frontier: The impact of a state-regulated marketing system. Land Use Policy, 28(2), 378387.

Krähmer, A., Engel, A., Kadow, D., Ali, N., Umaharan, P., Kroh, L. W., \& Schulz, H. (2015). Fast and neat-Determination of biochemical quality parameters in cocoa using near infrared spectroscopy. Food chemistry, 181, 152-159. 
Laird, S. A., Awung, G. L., \& Lysinge, R. J. (2007). Cocoa farms in the Mount Cameroon region: biological and cultural diversity in local livelihoods. Biodiversity and Conservation, 16(8), 2401-2427.

Laliberté, B., Cryer, N. C., Daymond, A. J., End, M. J., Engels, J. M., Eskes, A., ... \&Umaharan, P. (2012). A global strategy for the conservation and use of cacao genetic resources, as the foundation for a sustainable cocoa economy. http://agritrop.cirad.fr/568442/1/document_568442.pdf(Accessed 27 April 2018).

Leeuwis C., (2004) Innovation as a process of network building, social learning and negotiation implications for transdisciplinary research collaboration, Paper Presented at TransKARST 2004-International Transdisciplinary Conference on Development and Conservation of Karst Regions, Hanoi,Trans-KARST 2004, 137.

Levai, L. D., Meriki, H. D., Adiobo, A., Awa-Mengi, S., Akoachere, J. F. T. K., \&Titanji, V. P. (2015). Postharvest practices and farmers' perception of cocoa bean quality in Cameroon. Agriculture \& Food Security, 4(1), 28.

Lima, L. J. R. (2012). Microbial ecology of the cocoa chain: Quality aspects and insight into heat-resistant bacterial spores (Doctoral dissertation). https://digitalcommons.lsu.edu (accessed 27 April 2018).

Maalekuu, B. K., \& Teye, N. (2017). Comparative Evaluation of some Physical and Biochemical Quality Attributes of Cocoa Beans Produced in AssinFosu, AssinBereku and Nkawie Cocoa Districts of Ghana. Journal of Agricultural Science, 9(12), 169.

Mbonomo, R. B., Second, A., Medap, Z. E., Brecht, J. K., \&Eyame, G. (2016). A Study of the Combined Effect of Post-Harvest Fermentation, Turning and Drying of Cocoa ( Theobroma Cacao L .)On Beans Quality, Journal of Agricultural Sciences 3(16), 50235027.

Melorose, J., Perroy, R., \& Careas, S. (2014). Inventory of Existing and Exploitable Knowledge and Technologies on Cocoa and Maize Production in Ghana. Centre for Innovation and Technology Dissemination. 14(14),51.

Mohammed, D., Asamoah, D., \& Asiedu-Appiah, F. (2012). Cocoa value chain-implication for the smallholder farmer in ghana.

Monastyrnaya, E., Joerin, J., Dawoe, E., \& Six, J. (2016). Assessing the resilience of the cocoa value chain in Ghana. Case study report. Published by Swiss Federal Institute of Technology Zurich. https://www.researchgate.net. (Accessed 27 April 2018). 
Morales-Torres, J. (2007). Strategies for the prevention and control of osteoporosis in developing countries. Clinical Rheumatology, 26(7), 139-143.

Mbonomo RB, ZE Medap AS, Brecht JK, Eyame G, (2016) A Study of the Combined Effect of Post-Harvest Fermentation, Turning and Drying of Cocoa (Theobroma Cacao L.) On Beans Quality. Journal of Multidisciplinary Engineering Science and Technology (JMEST) 3(16), 2458-9403

Niemenak, N., Eyamo, A. J., Onomo, E. P., \&Youmbi, E. (2014). Physical and chemical assessment quality of cocoa beans in south and center regions of Cameroon. Syllabus Review, Science Series, 5, 27-33.

Nkrumah, K. (2014). Assessing the effectiveness of ghana's efforts at addressing child labour in cocoa growing communities (a case study of wassaamenfi west district of the western region).http://ir.knust.edu.gh/bitstream/123456789/7177/1/JOSHUA\%20ROLAND\%20B AIDOO.pdf. (Accessed 27 April, 2018).

Standards Organisation of Nigeria, (2004); Nigerian Code of Practice, Cocoa Beans-Harvesting and Handling (Code of Practice) DRAFT NCP XXX: 20XX

Norman, M., Darko, E., Whitley, S., Bawakyillenuo, S., \&Nyamedor, F. (2016). Mapping current incentives and investment in Ghana's agriculture sector: lessons for private climate finance'. London: ODI. 1-52. www.odi.orgNiemenaka. (Accessed 27 April 2018).

Eyamoa JA, Onomo PE, Youmbic E, (2014) Physical and chemical assessment quality of cocoa beans in south and center regions of CameroonSci. Ser. 5(14): 27 - 33.

Nunoo I, Frimpong B.N, Frimpong F.K,(2014). Fertilizer use among cocoa farmers in Ghana: the case of SefwiWiawso District.International Journal of Environment. 3(1) 1-5

Oke, D. O., \&Omotayo, K. F. (2012). Effect of forced-air artificial intermittent drying on cocoa beans in South-Western Nigeria. Journal of Cereals and Oilseeds, 3(1), 1-5.

Oluyole K.A., (2010). The effect of weather on cocoa production in different agroecological zones in Nigeria, World Journal of Agricultural Sciences 6 (10) 609-614.

Owusu-Boateng G, and Owusu SK, (2015) Methods of cocoa harvesting to drying of bean in Ghana and polycyclic aromatic hydrocarbon concentration in the nib and shell of the cocoa bean.; Academia Journal of Agricultural Research 3(9): 176-183.. 
Essegbey, G. O., \& Ofori-Gyamfi, E. (2012). Ghana cocoa industry-An analysis from the innovation system perspective. Technology and investment, 3(4), 276.

Peláez, P. P., Guerra, S., \& Contreras, D. (2016). Changes in physical and chemical characteristics of fermented cocoa (Theobroma cacao) beans with manual and semimechanized transfer, between fermentation boxes.ScientiaAgropecuaria, 7(2), 111-119.

Pohlan, H. A. J., \& Pérez, V. D. (2010). Growth and Production of Cocoa. Growth and Production of Cocoa. Retrieved from http://www.eolss.net/Eolss-sample All Chapter.aspx. (Accessed 27 April 2018).

Pritchard, M. (2014). A field practitioner's Guide: Institutional and organizational analysis and capacity strengthening. Rome: IFAD.

De Bruyn, F., Zhang, S. J., Pothakos, V., Torres, J., Lambot, C., Moroni, A. V., ...\& De Vuyst, L. (2017). Exploring the impacts of postharvest processing on the microbiota and metabolite profiles during green coffee bean production. Applied and environmental microbiology, 83(1), e02398-16.

Ponte, S., \& Gibbon, P. (2005). Quality standards, conventions and the governance of global value chains. Economy and society, 34(1), 1-31.

Knudsen, M. H., \& Fold, N. (2011). Land distribution and acquisition practices in Ghana's cocoa frontier: The impact of a state-regulated marketing system. Land Use Policy, 28(2), 378387.

Odame, E.A.,(2014). Effects Of Two Different Drying Mats At Different Loading Densities on the Physical And Chemical Qualities Of Cocoa Beans. Kwame Nkrumah University of Science and Technology, Kumasi School of Graduate Studies. http://ir.knust.edu.gh/bitstream/123456789/6459/1/Ebenezer\%20Odame\%20Anti..pdf. (Accessed 27 April 2018).

Oluyole K.A., The effect of weather on cocoa production in different agro- ecological zones in Nigeria, World Journal of Agricultural Sciences 6 (10) 609-614.

Onumah, J. A., Williams, P. A., Quaye, W., Akuffobea, M., \& Onumah, E. (2014). Smallholder Cocoa Farmers Access to On / Off-Farm Support Services and its Contribution to Output in the Eastern Region of Ghana. Asian Journal of Agriculture and Rural Development, 4(10), 484-495. 
International Journal of Agriculture and Environmental Research

ISSN: 2455-6939

Volume: 07, Issue: 04 "July-August 2021"

Opoku-Ameyaw K, Baah F, Anchirinah V, Dzahini-Obiatey H.K, Cudjoe R.A, Acquaye S, Opoku Y.S, (2010). Cocoa Manual—A Source Book for Sustainable Cocoa Production. Cocoa Research Institute of Ghana, Tafo

Owusu-Appiah, K. (2017). Assessment of farmers response to Good Agricultural Practices (GAP) training by (CHED) and its effect on the quality of cocoa beans in Nkawie Cocoa District. Retrieved from http://ir.knust.edu.gh(Accessed 27 April 2018).

Owusu-Boateng, G., \&Owusu, S. K. (2015). Methods of cocoa harvesting to drying of bean in Ghana and polycyclic aromatic hydrocarbon concentration in the nib and shell of the cocoa bean. Academia Journal of Agricultural Research, 3(9), 176-183.

Quarmine W, Haagsma R, Sakyi-Dawson O, Asante F, van Huis A, Obeng-Ofori D, (2012) Incentives for cocoa bean production in Ghana: Does quality matter? NJAS - Wageningen Journal of Life Sciences 60 (12) 7- 14

Quist-Wessel F. P.M, (2015). Review Cocoa production in West Africa, a review and analysis of recent developments.ScienceDirect NJAS - Wageningen Journal of Life Sciences journal homepage: www.elsevier.com/locate/njas. (Accessed 27 April 2018).

RiandaBaka, L., Aida AdhaTaridala, S., \&Saediman, H. (2015). Development Potential Of Cocoa Agroindustry In Southeast Sulawesi, Indonesia. IOSR Journal of Agriculture and Veterinary Science 1(2), 2-6.

Rosa, M. J., Sarrico, C. S., \&Amaral, A. (2012). Implementing Quality Management Systems in Higher Education Institutions. InTech, 131-146.www.intechopen.com. (Accessed 27 April 2018).

Saltini, R., Akkerman, R., \&Frosch, S. (2013). Optimizing chocolate production through traceability: A review of the influence of farming practices on cocoa bean quality. Food Control, 29(1), 167-187.

SAN (sustainable Agriculture Network), (2009) Sustainable Agriculture Standard for Rainforest Alliance

SAN (Sustainable Agricultural Network), (2008) Interpretation Guidelines-Indicators for Sustainable Cocoa Production in Ghana, Standards and Policy Secretariat Sustainable Agriculture Program Rainforest Alliance, October, 2008.

Schroeter, H., Heiss, C., Balzer, J., Kleinbongard, P., Keen, C. L., Hollenberg, N. K., ...\&Kelm, M. (2006). (-)-Epicatechin mediates beneficial effects of flavanol-rich cocoa on vascular 
International Journal of Agriculture and Environmental Research

ISSN: 2455-6939

Volume: 07, Issue: 04 "July-August 2021"

function in humans. Proceedings of the National Academy of Sciences, 103(4), 10241029.

Schroth, G., \& Harvey, C. A. (2007). Biodiversity conservation in cocoa production landscapes: an overview. Biodiversity and Conservation, 16(8), 2237-2244.

Schwan, R. F., \& Wheals, A. E. (2004). The microbiology of cocoa fermentation and its role in chocolate quality. Critical reviews in food science and nutrition, 44(4), 205-221.

Shapiro, H. Y., \&Rosenquist, E. M. (2004). Public/private partnerships in agroforestry: the example of working together to improve cocoa sustainability. Agroforestry Systems, 61(1-3), 453-462.

Smith, Scott (2013). "Determining Sample Size: How to Ensure You Get the Correct Sample Size Qualtrics". Qualtrics. https://a7852d97-a-62cb3ala-s-sites.googlegroups.com. (Accessed 27 April 2018).

Snoeck, D., Afrifa, A. A., Ofori-Frimpong, K., Boateng, E., \&Abekoe, M. K. (2010). Mapping fertilizer recommendations for cocoa production in Ghana using soil diagnostic and GIS tools. West African Journal of Applied Ecology, 17, 97-107.

Sukha, D. (2008). The influence of processing location, growing environment and pollen donor effects on the flavour and quality of selected cacao (Theobroma cacao L.) genotypes. $\mathrm{PhD}$ Thesis, Dept. Chem. Engineering of the University of the West Indies, St Augustine, Trinidad and Tobago.

Sukha, D. A. (2003). Potential value added products from Trinidad and Tobago cocoa. Proc. of Sem./Exhibition on The Revitalization on The Trinidad and Tobago Cocoa IndustryTargets, Problems and Options. The Association of Professional Agricultural Scients of Trinidad and Tobago (APASTT). Faculty of Science and Agriculture. The University of The West Indies. St. Augustine, 69-73.

Susniene, D., \&Jurkauskas, A. (2009). The concepts of quality of life and happiness-correlation and differences. Engineering Economics, 63(4).1392 - 2785.

Sova, C., Chaudhury, A., Nelson, W., Nutsukpo, D. K., \&Zougmoré, R. (2014). Climate Change Adaptation Policy in Ghana: Priorities for the Agriculture Sector, (68), 84.https://cgspace.cgiar.org.(Accessed 27 April 2018).

Raikes, P., Friis Jensen, M., \& Ponte, S. (2000). Global commodity chain analysis and the French filière approach: comparison and critique. Economy and society, 29(3), 390-417. 
Rifin, A. (2013). Competitiveness of Indonesia's cocoa beans export in the world market. International Journal of Trade, Economics and Finance, 4(5), 279.

Takane, T. (2000). Incentives embedded in institutions: the case of share contracts in Ghanaian cocoa production. The Developing Economies, 38(3), 374-397.

Tate,J., \& Panteghini, M., (2007) Standardisation - The Theory and the Practice. Centre for Metrological Traceability in Laboratory Medicine (CIRME), University of Milan, 20157 Milano, Italy.

Taubert, D., Roesen, R., \& Schömig, E. (2007). Effect of cocoa and tea intake on blood pressure: a meta-analysis. Archives of internal medicine, 167(7), 626-634.

Teal, F., Zeitlin, A., \& Maamah, H. (2006). Ghana cocoa farmers survey 2004: report to Ghana Cocoa Board. CSAE-Oxford University.https://www.researchgate.net (Accessed 27 April 2018).

Tiffen, P., MacDonald, J., Maamah, H., \& Osei-Opare, F. (2004). From tree-minders to global players: Cocoa farmers in Ghana. Chains of Fortune Linking Women Producers and Workers with Global Markets. London. Commonwealth Secretariat, 11-44.

Ryan, J. (2012). Infrastructures for peace as a path to resilient societies: An institutional perspective. Journal of Peacebuilding \& Development, 7(3), 14-24.

Turner, M. (2002). Choosing items from the menu: New public management in Southeast Asia. International Journal of Public Administration, 25(12), 1493-1512.

Vermeulen, W.J.V and Seuring, S. (2009) "Sustainability through the market - The Impact of Sustainable Supply Chain Management: Introduction Sustainable Development, Vol. 17, pp. $269-273$

Waliyar F., Osiru1, M., Ntare, B.R.,, Vijay K., Krishna K., Sudini H., Traore K., and Diarra, B., (2015) International Crops Research Institute for the Semi-Arid Tropics (ICRISAT), BP 320, Bamako, Mali; 2ICRISAT, 502324.https://core.ac.uk/download/pdf/129738919.pdf(Accessed 27 April 2018).

Woodhill, J. (2008). Institutional Change-A Framework for analysis. Wageningen International. Occasional paper, Wageningen International. http://negowat.cirad.fr/Docs4Web/Brazil_pdf/12_Brazil.pdf(Accessed 27 April 2018). 
Yaro, J. A. (2013). The perception of and adaptation to climate variability/change in Ghana by small-scale and commercial farmers. Regional Environmental Change, 13(6), 1259-1272.

Yao, K. M., Kambiré, O., Kouassi, K. C., Koffi-Névry, R., \& Guéhi, T. S. (2017). Risk Prevention of Fungal Contamination of Raw Cocoa Beans in Côte d'Ivoire: Case of Polyhexamethylene Guanidine Hydrochloride (PHMGH). Food and Public Health, 7(2), 40-50.

Yusof, M. A. S.; Lamin, K.; Lee, M. T. and Rosman, R. (2000) High yielding cocoa plots in Peninsular Malaysia - A case study. Proceedings of the Malaysian International CocoaConference, 1998, M. T. Lee, K. Lamin, L. Johnsiul, D. B. Furtek and F. L. Ening (eds.),Malaysian Cocoa Board, Kuala Lumpur, 45 - 48.

Zanoli R., Gambelli D., Vitulano S., (2007): Conceptual Framework on the Assessment of the Impact of Organic Agriculture on the Economies of Developing Countries. Polytechnic University of Marche, Ancona- Italy. 